\title{
Oxidation Inhibition Mechanism and Performance of a New Protective Coating for Slab Reheating of $3 \%$ Si-steel
}

\author{
Hisao ODASHIMA') and Makoto KITAYAMA ${ }^{2)}$
}

1) Hirohata R \& D Lab., Nippon Steel Corporation, Fuji-machi, Hirohata-ku, Himeji, Hyogo-ken, 671-11 Japan. 2) R \& D Laboratories-II, Nippon Steel Corporation. Now at Chugoku Toryo Co., Ltd., Uchisaiwai-cho, Chiyoda-ku, Tokyo, 100 Japan.

(Received on June 22, 1989; accepted in the final form on September 8, 1989)

\begin{abstract}
This study was carried out to clarify the properties and antioxidation mechanisms of newly developed oxidation inhibitor consisting of refractory powder- $\mathrm{SiO}_{2}-\mathrm{Si}-\mathrm{SiC}$-synthetic mica-colloidal silica-surface active agent and caking bond. By applying this type of oxidation inhibitor to grain-oriented silicon steel, it was possible to achieve significant reductions in scaling and production of fayalite-based slag, thereby substantially increasing yield.

During heating, $\mathrm{Al}_{2} \mathrm{O}_{3}$ is formed as a result of the decomposition by $\mathrm{Si}$ (metallic silicon) of mullite $\left(3 \mathrm{Al}_{2} \mathrm{O}_{3} \cdot 2 \mathrm{SiO}_{2}\right)$ contained in refractory powder. Furthermore, the fine $\mathrm{SiC}$ powder is oxidized and changes gradually to protective cristobalite- $\mathrm{SiO}_{2}\left(\mathrm{C}-\mathrm{SiO}_{2}\right)$ layer which acts as an excellent barrier to oxygen diffusion from atmosphere. The protective $\mathrm{C}-\mathrm{SiO}_{2}$ is not formed from the $\mathrm{C}-\mathrm{SiO}_{2}$ which is added initially in the oxidation inhibitor but is newly formed through the oxidation process of the $\mathrm{SiC}$.

On the other hand, $\mathrm{Al}_{2} \mathrm{O}_{3}$ which is formed by the decomposition of mullite becomes $\mathrm{Al}_{2} \mathrm{O}_{3} \cdot \mathrm{SiO}_{2}$ in combination with $\mathrm{SiO}_{2}$. On the steel surface, however, it becomes highly protective $\mathrm{FeO} \cdot \mathrm{Al}_{2} \mathrm{O}_{3}$ or $3 \mathrm{FeO} \cdot \mathrm{Al}_{2} \mathrm{O}_{3} \cdot 3 \mathrm{SiO}$ layer and, at the same time, it prevents the formation of low melting point material such as fayalite $\left(2 \mathrm{FeO} \cdot \mathrm{SiO}_{2}\right)$.

It has been clarified that this oxidation inhibitor exhibits the excellent antioxidability due to superposed effect of abovementioned reactions.
\end{abstract}

KEY WORDS: heating furnace; oxidation inhibitor; surface treatment; grain oriented silicon steel; chamotte; slab; slag; heating temperature; fayalite; scale.

\section{Introduction}

Traditionally, grain-oriented silicon steel has been produced by means of a process involving the prolonged (generally $3-8 \mathrm{~h}$ ) heating of the casting (slab) in a high-temperature heating furnace at temperatures of 1350 to $1400^{\circ} \mathrm{C}$.

Grain-oriented silicon steel contains approximately $3 \%$ of $\mathrm{Si}$. The characteristic of $3 \% \mathrm{Si}$ steel is responsible for the formation of scale consisting mainly of fayalite $\left(2 \mathrm{FeO} \cdot \mathrm{SiO}_{2}\right)$ during heating. Fayalite has a melting point of $1205^{\circ} \mathrm{C},{ }^{1}$ ) while the eutectic crystal temperature of $\mathrm{Fe}-2 \mathrm{FeO} \cdot \mathrm{SiO}_{2}$ is $1170^{\circ} \mathrm{C},{ }^{1)}$ which is considerably lower than the heating temperature. As a result, the scale is melted during heating and accumulates in the furnace bed as slag. The production of scale and slag generally reduces yield by $3.5-6.0 \%$ on a weight basis. Moreover, the accumulation of large amounts of slag in the furnace bed causes a substantial deterioration of furnace operating rates and makes maintenance difficult.

The use of oxidation inhibitor was therefore considered as a means of overcoming the various problems associated with the production of grain-oriented silicon steel.

A number of problems have to be overcome when an oxidation inhibitor is applied to $3 \% \mathrm{Si}$ steel.

(1) Oxidation inhibitor used with $3 \% \mathrm{Si}$ steel must provide excellent antioxidability during $3-8 \mathrm{~h}$ heating at $1350-1450^{\circ} \mathrm{C}$.

(2) It must also provide adequate resistance against extreme slag corrosion.

(3) The condition in which the slab (coating) is maintained in the heating furnace have a major effect on the characteristics (magnetism) of grain-oriented silicon steel, and it is therefore essential to apply an oxidation inhibitor film with superior absorption and thermal conduction.

(4) It is particularly important that the film has flaked off completely when the steel passes through the scale breaker (RSB), since any residue remaining after rolling would seriously affect the value of the finished product.

The authers have already discussed an oxidation inhibitor composed of refractory powder- $-\mathrm{SiO}_{2}-\mathrm{Al}-$ synthetic mica-colloidal silica-caking agent (metallic aluminum oxidation inhibitor $\left.{ }^{3,4}\right)$ in a previous report. ${ }^{2 !}$

The oxidation inhibition mechanism of this inhibitor is explained as follows. During heating, metallic aluminum becomes the mullite $\left(3 \mathrm{Al}_{2} \mathrm{O}_{3} \cdot 2 \mathrm{SiO}_{2}\right)$ in refractory powder (chamotte) into $\mathrm{Al}_{2} \mathrm{O}_{3}$ and $\mathrm{SiO}_{2}$ and further decomposes the formed $\mathrm{SiO}_{2}$ and the added $\mathrm{SiO}_{2}$ with the formation of metallic silicon. This metallic silicon is oxidized by the oxygen in the air and gradually forms a protectiveamorphous $\mathrm{SiO}_{2}$ 
film, which prevents the diffusion of $\mathrm{O}^{--}$ions thereafter. After the decomposition of mullite and $\mathrm{SiO}_{2}$, aluminum is oxidized with the formation of an $\alpha$ $\mathrm{Al}_{2} \mathrm{O}_{3}$ film and an $\mathrm{FeO} \cdot \mathrm{Al}_{2} \mathrm{O}_{3}$ film, which also have a high protective power. In this inhibitor, the formation of low-melting substances, such as fayalite $(2 \mathrm{FeO}$. $\mathrm{SiO}_{2}$ ), is suppressed due to the formation of $\mathrm{FeO}$. $\mathrm{Al}_{2} \mathrm{O}_{3}$ and hence the protective films exit stably even during long-time heating. Many pores are formed due to a volume decrease resulting from the chemical reaction $\mathrm{Al} \rightarrow \mathrm{Al}_{2} \mathrm{O}_{3}$ and $\mathrm{SiO}_{2} \rightarrow$ Si.

These pores also constitute barriers to the diffusion of $\mathrm{Fe}^{++}$and $\mathrm{O}^{--}$ions. It was found that this inhibitor shows an excellent oxidation preventive capacity owing to the above-mentioned combined actions.

The metallic aluminum oxidation inhibitor maintains excellent antioxidability, and its effectiveness in the limitation of selective oxidation inhibition in alloy elements and intergranular oxidation makes it the ideal substance for use with special steels. But it does not show superior heat conductivity and heat absorption, and there is difference between the coated and uncoated samples in terms of the post-heating condition of the steel. This means that there is difference between the coated and uncoated samples in terms of magnetism, and the same level of magnetism is not recorded with $3 \% \mathrm{Si}$ steel that have been coated with metallic aluminum oxidation inhibitor as compared with uncoated $3 \%$ Si steel.

The authors have found after repeated studies that all of the above-mentioned requirements can be satisfied by oxidation inhibitor consisting of refractory powder- $\mathrm{SiO}_{2}-\mathrm{Si}-\mathrm{SiC}$-synthetic mica-colloidal silicasurface active agent-caking bond agent ${ }^{5-7)}$ (referred to in this report as " $\mathrm{Si}-\mathrm{SiC}$ oxidation inhibitor").

This report was written to clarify the properties of $\mathrm{Si}-\mathrm{SiC}$ oxidation inhibitor when it was applied to $3 \% \mathrm{Si}$ steel, and to describe the results of an analysis of the antioxidation mechanisms of these substances.

\section{Method of Experiment}

\subsection{Characteristics of $\mathrm{Si}-\mathrm{SiC}$ Oxidation Inhibitor}

2.1.1. Confirmation of Antioxidability through Fundamental Experimentation

Antioxidability in relation to grain-oriented silicon steel was determined according to the method described below.

(i) Samples:

Conventional grain-oriented silicon (CGO) steel and HI-B steel were used as samples. The chemical compositions of the samples were as shown in Table 1. The materials were cut into $100 \times 100 \times 100 \mathrm{~mm}^{3}$ pieces and preheated to $300^{\circ} \mathrm{C}$, since grain-oriented

Table 1. Chemical composition of specimens. (wt \%)

\begin{tabular}{cccc} 
& Si & Mn & Sol. Al \\
\hline CGO steel & $3.20-0.30$ & $0.05-0.07$ & $<0.01$ \\
HI-B steel & $3.20-3.30$ & $0.07-0.09$ & $0.024-0.032$ \\
\hline
\end{tabular}

silicon steel is normally placed in the heating furnace as warm slabs $\left(100-400^{\circ} \mathrm{G}\right)$ or hot slabs (400-1 000

$\left.{ }^{\circ} \mathrm{C}\right)$. The oxidation inhibitor was then applied.

(ii) Composition of oxidation inhibitor:

Chamotte $\left(3 \mathrm{Al}_{2} \mathrm{O}_{3} \cdot 2 \mathrm{SiO}_{2}\right)$

Silicic acid anhydride

100 (by weight)

Si powder (metallic Si powder) 30 (by weight)

$\mathrm{SiC}$ powder

Synthetic mica $\left(\mathrm{K}_{1 / 3} \cdot \mathrm{Mg}_{5 / 2}\right.$.

$\left.\mathrm{Li}_{1 / 3}\left(\mathrm{Si}_{4} \mathrm{O}_{12}\right) \cdot \mathrm{F}_{2}\right)$

Colloidal silica (solid)

Carboxylic acid type surface active agent

Sodium polyacrylic acid

$\mathrm{H}_{2} \mathrm{O}$

150 (by weight)

5 (by weight)

4.5 (by weight)

2 (by weight)

16 (by weight)

145 (by weight)

(iii) Amount applied: $0.5-2.0 \mathrm{~kg} / \mathrm{m}^{2}$ (solid)

(iv) Method of application:

When the required amount was applied in a single application, the residual heat of the samples caused bumping of the water in the film, leading to the formation of a porous film. The film was therefore formed by means of several automatic applications.

(v) Drying:

The film dried in an extremely short period $(2-3 \mathrm{~s})$ due to the residual heat of the samples.

(vi) Heating condition:

The samples preheated at $300^{\circ} \mathrm{C}$ were heated to $1380^{\circ} \mathrm{C}$ (sample temperature) over a period of $2 \mathrm{~h}$. After soaking for $2 \mathrm{~h}$ (total furnace time: $4 \mathrm{~h}$ ), the samples were extracted from the furnace. Heating was carried out in an air atmosphere.

(vii) Measurement of antioxidability:

Antioxidability was determined by measuring the weight loss of the heated samples.

The method of measurement was as described in the previous report. ${ }^{2)}$

2.1.2. Measuring of Heat Conduction of Film through Fundamental Experimentation

The oxidation inhibitor was applied to $3 \%$ Si steel into which thermocouples had been inserted. The heating curves of the steel were then measured. The test was carried out under the following conditions.

1) Chemical composition of samples: As stated in Table 1

2) Size of samples: $200 \times 400 \times 500 \mathrm{~mm}^{3}$

3) Oxidation inhibitor application rate: $1.5 \mathrm{~kg} / \mathrm{m}^{2}$ (solid)

4) Heating condition: $4 \mathrm{~h}$ at $1380^{\circ} \mathrm{C}$

5) Confirmation position: $5 \mathrm{~mm}$ depth from the surface of sample center.

2.1.3. Confirmation of Properties in Production Line

Experiments were carried out in a continuous hot rolling mill at Nippon Steel's Hirohata Works to ascertain the antioxidation effect (improvement in yield) and the effect on surface scratching, magnetism and so on when $\mathrm{Si}-\mathrm{SiC}$ oxidation inhibitor was applied production samples.

(i) Casting: $3 \%$ Si steel was used.

(ii) Oxidation inhibitor:

The composition of the oxidation inhibitor was the 
same as stated in Sec. 2.1.1. The rate of application was $1.5 \mathrm{~kg} / \mathrm{m}^{2}$, and the substance was applied up to the required amount by means of several automatic applications.

(iii) Heating:

All samples were heated in a walking beam continuous reheating furnace.

(iv) Evaluation:

(1) Yield (antioxidability)-Yield was calculated by subtracting the weight of the coil after rolling from the weight of the cast slab (steel piece), to determine the amount of iron lost through scale and slag.

(2) Flaking of oxidation inhibitor during hot rolling-This was evaluated by observing the amount of residual oxidation inhibitor when the sample passed through the RSB.

(3) Observation of post-heating condition of slabs -Identical slabs, one coated with the oxidation inhibitor and the other uncoated (control sample) were placed in the heating furnace in pairs. After removal from the furnace, the slabs were cut and their postheating condition was determined through measurement of the macrograin growth rate.

(4) Surface scratches-The surface of the finished coil was divided into band-shaped sections along the longitudinal (5 sections across the width of the coil) and latitudinal (at $200 \mathrm{~mm}$ intervals along the length of the coil) axes. The number of sections containing even one surface scratch was determined and expressed as a percentage of the total number of sections. Surface scratches were classified as "hard" (deep) or " slight" (shallow) defects.

(5) Magnetism-After hot rolling, the samples were processed into sheets according to the usual production processes for grain-oriented silicon steel. They were surveyed for core loss (core loss $W_{17 / 50}$ ( 1.7 Tesla, $50 \mathrm{~Hz})(\mathrm{W} / \mathrm{kg})$ ) and magnetic flux density (Induction $\mathrm{B}_{10}(\mathrm{~T})$ ).

\subsection{Analysis of the Physical Characteristics and Behavior of $\mathrm{Si}-\mathrm{SiC}$ Oxidation Inhibitor}

An oxidation inhibitor consisting of the constituents listed in problem (1) in Chap. 1 was prepared for use in the measurements. All measurement items and conditions were the same as in the previous report. ${ }^{2)}$

\section{Results of Experiment}

\subsection{Oxidation-preventive Capacity}

A study was carried out to determine how antioxidability is affected by the grain size of the $\mathrm{SiC}$ contained in $\mathrm{Si}-\mathrm{SiC}$ oxidation inhibitor. $\mathrm{CGO}$ steel was used as the raw material, and the new inhibitor was applied at the rate of $1.5 \mathrm{~kg} / \mathrm{m}^{2}$. The grain size of the $\mathrm{SiC}$ had a major impact on antioxidability, which improved as the grain size became smaller. Fig. 1 shows that antioxidability was particularly good with grain sizes of $10 \mu$ or less. The same tendency was observed with HI-B steel.

It was therefore decided to need $\mathrm{SiC}$ in the $\mathrm{Si}$ $\mathrm{SiC}$ oxidation inhibitor in the form of a fine powder with a grain size of $10 \mu$ or less.
The relationship between the rate of application and the antioxidability of $\mathrm{Si}-\mathrm{SiC}$ oxidation inhibitor is shown in Fig. 2. Under condition heated from 300 to $1380^{\circ} \mathrm{G}$ over a $120 \mathrm{~min}$ period, followed by 120 min soaking at $1380^{\circ} \mathrm{G}$, uncoated $3 \%$ si steel showed a substantial loss of iron volume $\left(175 \mathrm{~g} / \mathrm{dm}^{2}\right)$ due to the formation of $2 \mathrm{FeO} \cdot \mathrm{SiO}_{2}$ (fayalite) as a result of oxidation, and the outflow of slag based on these substances. There was a marked reduction in loss of iron volume when the samples were coated with $\mathrm{Si}-$ $\mathrm{SiC}$ oxidation inhibitor. Increase in the rate of application brought major improvement in antioxidability. It was possible to reduce scaling and slag formation to $1 / 20-1 / 30$ compared with uncoated samples at $1.0 \mathrm{~kg} / \mathrm{m}^{2}$, and to $1 / 80-1 / 100$ at $1.5 \mathrm{~kg} / \mathrm{m}^{2}$.

The relationship between soaking time and antioxidability is shown in Fig. 3. The samples were heated from 300 to $1380^{\circ} \mathrm{C}$ over a $2 \mathrm{~h}$ period, followed by soaking at $1380^{\circ} \mathrm{C}$. The samples were then examined to determine the effect of the length of the heating period on antioxidability with different application rates. It was found that antioxidability declined slightly when the soaking time was increased,

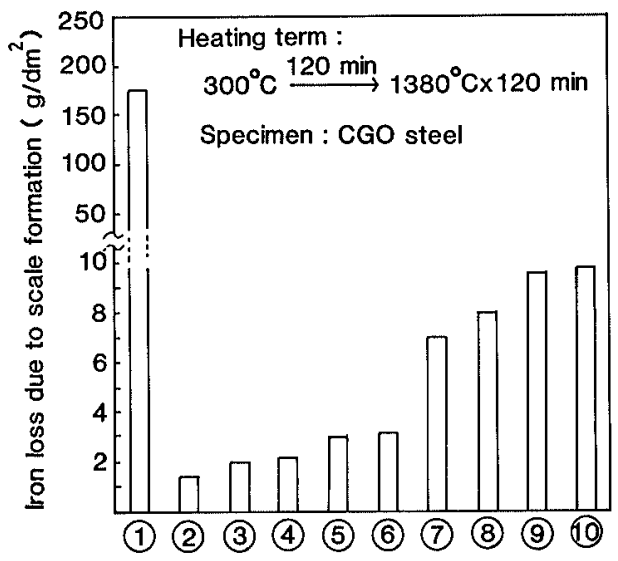

(1): Non coated steel

(2) (10): Coated steel

(2): SiC under $10 \mu \mathrm{m}$ (3): SiC 15 $25 \mu \mathrm{m}$

(4): SiC $25 \sim 35 \mu \mathrm{m}$ (5): $\mathrm{SiC} 35 \sim 45 \mu \mathrm{m}$

(6) : SiC $45 \sim 55 \mu \mathrm{m}$ (7): $\mathrm{SiC} 65 \sim 75 \mu \mathrm{m}$

(8): SiC $95 \sim 105 \mu \mathrm{m}$ (9): SiC $145 \sim 155 \mu \mathrm{m}$

(10) : SiC $195 \sim 205 \mu \mathrm{m}$

Fig. 1. Relationship between size of $\mathrm{SiC}$ in the oxidation inhibitor and iron loss due to scale formation.

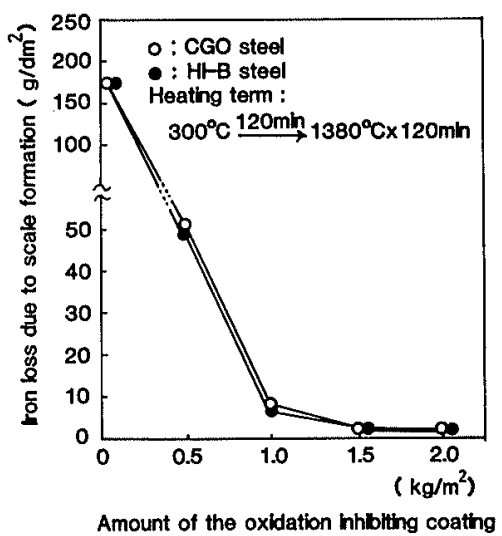

Fig. 2. Effect of the amount of the oxidation inhibiting coating on iron loss due to scale formation. 


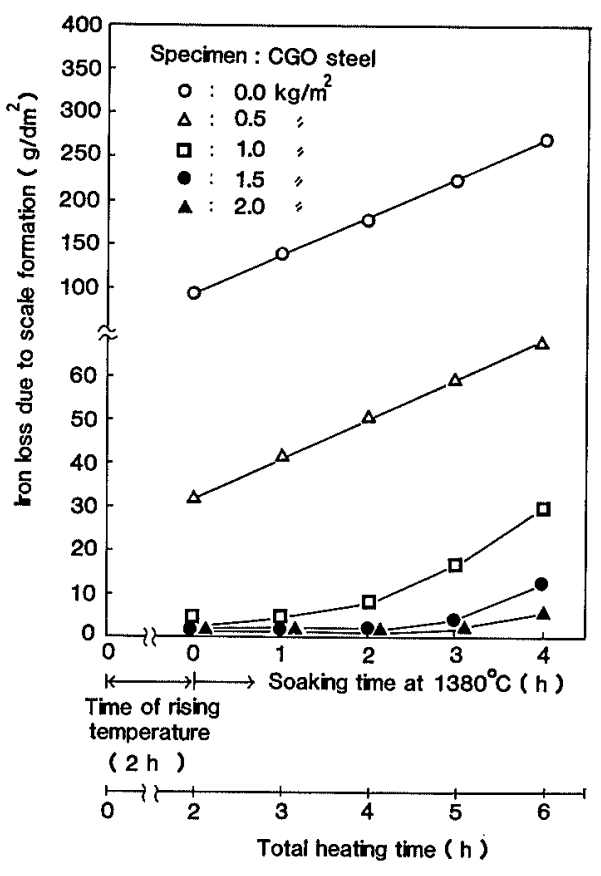

Fig. 3. Effect of the amount of the oxidation inhibiting coating and the heating time on iron loss due to scale formation.

but that this tendency diminished when the application rate was increased. At $1.5 \mathrm{~kg} / \mathrm{m}^{2}$, the oxidation inhibitor maintained a high level of antioxidability, even after prolonged heating. The findings shown in Figs. 2 and 3 refer to GGO steel. Similar results were obtained with HI-B steel.

\subsection{Heat Absorption and Heat Condition Characteristics of the Oxidation Inhibitor Film}

Fig. 4 shows the heating curve of a $3 \%$ Si steel slab coated with an $\mathrm{Si}-\mathrm{SiC}$ oxidation inhibitor. When the salb was coated with the oxidation inhibitor that did not contain $\mathrm{SiC}$, the rate of temperature increase was significantly slower than in the case of an uncoated slab. However, the addition of $\mathrm{SiC}$ improved the heat absorption and heat conduction characteristics of the oxidation inhibitor film. The degree of improvement increased in proportion to the grain size of the $\mathrm{SiC}$. Slabs coated at the rate of $1.5 \mathrm{~kg} / \mathrm{m}^{2}$ with the oxidation inhibitor containing finely powdered $\mathrm{SiC}$ (particularly $10 \mu \mathrm{m}$ or less) yielded heating curves that were virtually the same as those of uncoated slabs.

\subsection{Confirmation of Properties in Production Line}

\subsubsection{Hot Rolling Yield}

$\mathrm{Si}-\mathrm{SiC}$ oxidation inhibitor was applied to the obverse or obverse and reverse (not sides) of $3 \% \mathrm{Si}$ steel slabs of various sizes at the rate of $1.5 \mathrm{~kg} / \mathrm{m}^{2}$. Production line tests were carried out in the continuous hot rolling mill to confirm the properties of these slabs. The $3 \% \mathrm{Si}$ steel slabs were put into the heating furnace warm $\left(100-400^{\circ} \mathrm{C}\right)$ or hot $\left(400-1000^{\circ} \mathrm{C}\right)$. To prevent the formation of a porous film due to bumping of the water in the oxidation inhibitor, the substances were sprayed on the slab surface in several

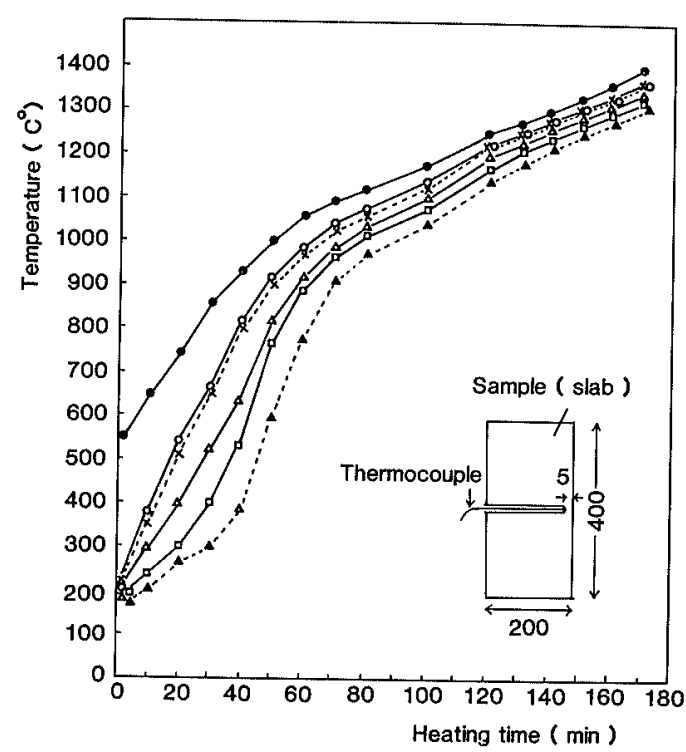

Slab size : $200 \times 400 \times 500 \mathrm{~mm}$ Specimem : CGO steel

$$
\begin{aligned}
& \longleftrightarrow \text { : Temperature of the atmosphere }
\end{aligned}
$$

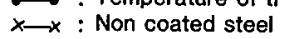

$$
\begin{aligned}
& \circ \text { : Coated steel ( } \mathrm{SiC}: \text { under } 10 \mu \mathrm{m} \text { ) } \\
& \leftrightarrow: \quad \text { : (SiC: } 45 \sim 55 \mu \mathrm{m} \text { ) } \\
& \leadsto: \quad=\quad(3: 195 \sim 205 \mu \mathrm{m}) \\
& \text { Amount of the coating: } 1.5 \mathrm{~kg} / \mathrm{m}^{2}
\end{aligned}
$$

Fig. 4. Heating curves of coated and non-coated slabs.

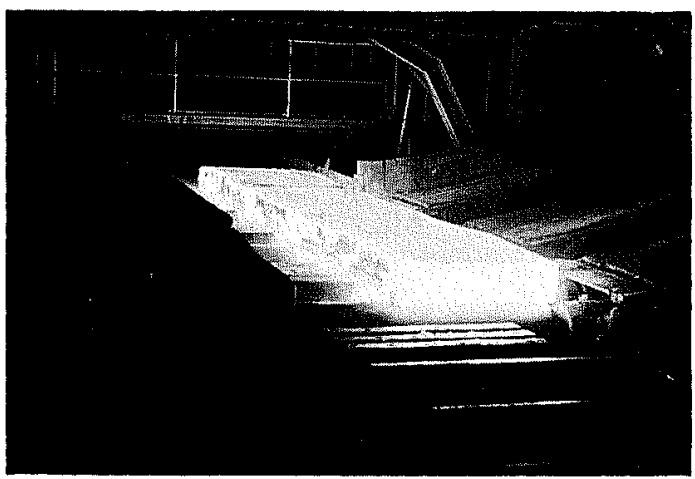

Slab: Coated CGO steel (Coating weight: $1.5 \mathrm{~kg} / \mathrm{m}^{2}$ )

Fig. 5. External appearance of obverse of slab discharged from heating furnace.

applications with an automatic painting system until the required volume was attained. This method ensured the formation of a finely textured film. Si-SiC oxidation inhibitor drys extremely quickly due to the residual heat of the slabs, and operating conditions were excellent. After treatment, the slabs were suspended from magnets or wires and placed on table rollers, which moved them into a walking beam continuous reheating furnace. Si-SiC oxidation inhibitor films exhibited excellent adhesion to the slabs and there were virtually no signs of film flaking during these operations. All slabs were plated in the furnace in pairs, one coated with the $\mathrm{Si}-\mathrm{SiC}$ oxidation inhibitor and the other an identical uncoated slab (control sample). After heating under the appropriate conditions for $3 \% \mathrm{Si}$ steel, the slabs were hot rolled. Fig. 5 shows the external appearance of the slab surface immediately after withdrawal from the reheating furnace. The oxidation inhibtor film remained sta- 
ble, even under the extreme heating conditions required for $3 \% \mathrm{Si}$ steel, and there was no corrosion of the film, even by the slag that formed on some of the slabs. The oxidation inhibitor film adhered firmly to the slab until it was withdrawn from the reheating furnace, and there was almost no indication of film separation inside the furnace. $\mathrm{Si}-\mathrm{SiC}$ oxidation inhibitor exhibited excellent separation characteristics during hot rolling, and all slabs showed $100 \%$ flaking by the time they passed through the RSB. The results of measurements of hot rolling yield are shown in Fig. 6. Applications of $\mathrm{Si}-\mathrm{SiC}$ oxidation inhibitor to the obverse (not the back or sides) of the slabs at rates of $1.0,1.2$ and $1.5 \mathrm{~kg} / \mathrm{m}^{2}$ produced improvements of $1.28,1.32$ and $1.59 \%$, respectively, in hot rolling yield compared with those of uncoated slabs (based on average value). Improvements of 2.31, 2.43 and $2.85 \%$, respectively, were obtained when the oxidation inhibitor were applied to the obverse and reverse (but not sides) of the slabs at the rate of $1.0,1.2$ and $1.5 \mathrm{~kg} / \mathrm{m}^{2}$. HI-B steel showed a similar tendency to CGO steel.

\subsubsection{Post-heating Condition of Slabs}

The post-heating condition of a pair of CGO steel slabs, one coated with an $\mathrm{Si}-\mathrm{SiC}$ oxidation inhibitor and the other uncoated, was determined from the

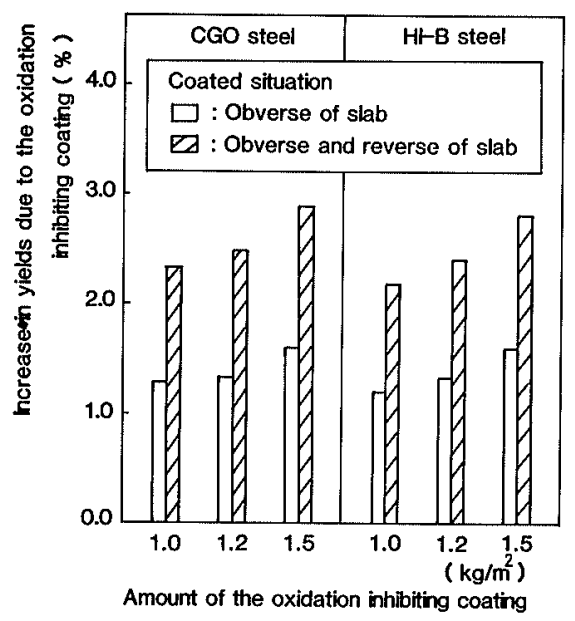

Fig. 6. Increase in production yields due to the oxidation inhibiting coating. macrograin growth rate of each slab after withdrawal from the reheating furnace. It was found that there was virtually no difference in the macrograin growth rates of coated and uncoated slabs. The uncoated slab had a macrograin growth rate of $88 \%$, compared with $89 \%$ for a slab whose obverse face had been coated at the rate of $1.5 \mathrm{~kg} / \mathrm{m}^{2}$ and $88 \%$ for a slab whose obverse and reverse faces had been coated at the rate of $1.5 \mathrm{~kg} / \mathrm{m}^{2}$ (sides uncoated in both cases).

This indicates that the excellent heat absorption and heat conduction of $\mathrm{Si}-\mathrm{SiC}$ oxidation inhibitor enable the same post-heating condition to be obtained in coated slabs as in uncoated slabs.

\subsubsection{Surface Scratches}

Fig. 7 shows the incidence of surface scratching in finished products. The scratches are classified into hard scratches and slight scratches. Neither the CGO steel nor HI-B steel showed any surface scratching that could be attributed to residual $\mathrm{Si}-\mathrm{SiC}$ oxidation inhibitor. Also, no significant difference was apparent between the coated and uncoated samples in terms of the incidence of scratching due to other causes (primaly and secondary scaling etc.). The overall incidence of hard and slight scratching was the same in both cases.

\subsubsection{Magnetism}

Figs. 8 and 9 show the magnetism of $0.3 \mathrm{~mm}$ CGO steel coated with the $\mathrm{Si}-\mathrm{SiC}$ oxidation inhibitor. No significant difference was noted between coated and uncoated steel. Coated steel showed an average core loss of $1.181\left(\mathrm{~W}_{17 / 50} \mathrm{~W} / \mathrm{kg}\right)$ and an average magnetic flux dencity of $1.873\left(\mathrm{~B}_{10} \mathrm{~T}\right)$. With uncoated steel, the former was $1.201(\mathrm{~W} / \mathrm{kg})$ and the latter $1.864(\mathrm{~T})$. The same tendency was apparent with HI-B steel.

Exactly the same level of magnetism can be obtained in steel coated with the $\mathrm{Si}-\mathrm{SiC}$ oxidation inhibitor as in uncoated steel. This result is probably to be expected in view of the fact there was no difference between the post-heating condition of coated and uncoated samples after withdrawal.

\subsection{Analysis of Behavior of $\mathrm{Si}-\mathrm{SiC}$ Oxidation Inhibitor}

3.4.1. Weight Ghanges and Endothermic and Exothermic Reactions of Film during Heating

As the temperature rises, the amount of $\mathrm{H}_{2} \mathrm{O}$
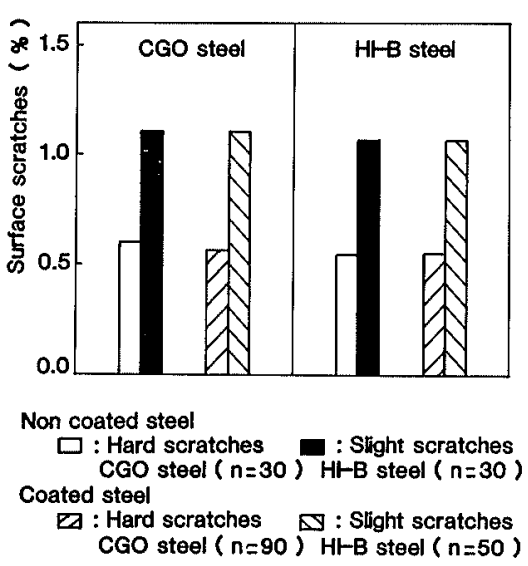

Fig. 7. Scratches of steel sheet surface.

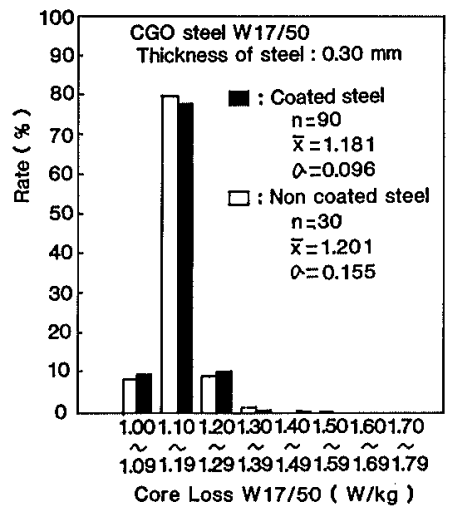

Fig. 8. Magnetism of coated and noncoated GGO steels.

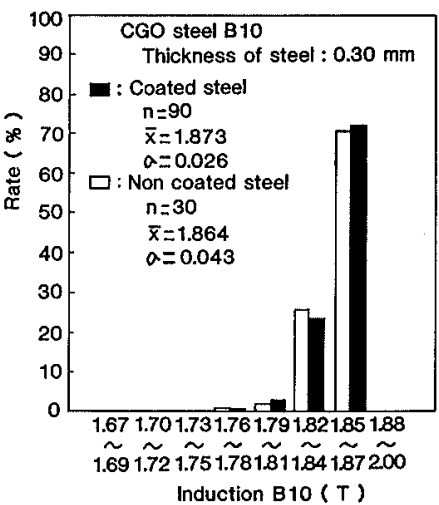

Fig. 9. Magnetism of coated and noncoated CG steels 
gradually decreases until total dissipation at $100-$ $150^{\circ} \mathrm{C}$. The sodium polyacrylic acid (caking bond) gradually separates next, and is fully dissipated at $500-600^{\circ} \mathrm{C}$. This is followed by a gradual weight increase, which continues even at quite high temperatures and is an indication of continuing chemical reactions.

\subsubsection{Changes in Chemical Composition of Film due to Heating}

$\mathrm{SiC}$ grain size is an important factor in relation to the $\mathrm{Si}-\mathrm{SiC}$ oxidation inhibitor. We have already reported (Fig. 1) that antioxidability improves as grain size becomes finer.

Studies were carried out to determine by means of high-temperature X-ray diffraction how the chemical composition of the oxidation inhibitor film changes during heating with different $\mathrm{SiC}$ grain sizes and $\mathrm{SiC}$ concentrations. Fig. 10 shows changes in the chemical composition of the oxidation inhibitor containing $\mathrm{SiC}$ with grain sizes of $10 \mu$ or less (150 parts added) to which no Si has been added.

At high temperatures, there is a minute decrease in the level of $\alpha$-SiG and mullite (Chamotte: $3 \mathrm{Al}_{2} \mathrm{O}_{3}$. $2 \mathrm{SiO}_{2}$ ), and a moderate increase in the level of cristobalite- $\mathrm{SiO}_{2}\left(C-\mathrm{SiO}_{2}\right)$. No peak was observed throughout the test for (111) face reflection of $\mathrm{Si}$ but a minute trace of (220) face reflection of $\mathrm{Si}$ was observed from $1000^{\circ} \mathrm{C}$ onwards. The findings in Fig. 11 relate to the oxidation inhibitor containing fine $\mathrm{SiG}$ with a grain size of $10 \mu$ or less ( 150 parts added) to which 30 parts of $\mathrm{Si}$ has also been added. The presence of Si causes significant variations in the behavior of the substance. There is a rapid decrease in the level of $\alpha-\mathrm{SiC}$ after $800^{\circ} \mathrm{C}$. Virtually no mullite can be detected after $1000^{\circ} \mathrm{C}$, indicating that most has already been separated. The level of (111) face reflection of Si gradually decreases as the temperature rises, but there is a rapide increase in (220) face reflection of $\mathrm{Si}$ after $1000^{\circ} \mathrm{C}$. There is also a corresponding increase in $\mathrm{C}-\mathrm{SiO}_{2}$. Fig. 12 shows the results obtained with extremely coarse $\alpha$-SiC (195$205 \mu$ ). There was virtually no decrease in $\alpha-\mathrm{SiC}$

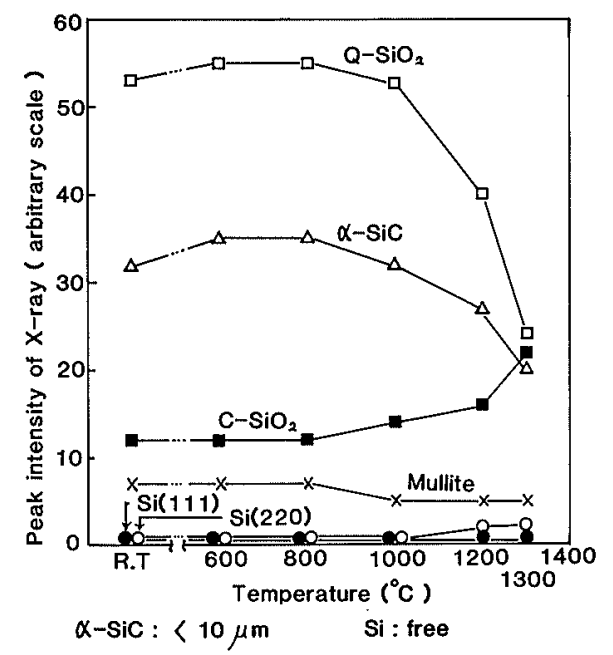

Fig. 10. Variation in composition of Si free oxidation inhibitor with temperature. and the only difference was a slight increase in $C-\mathrm{SiO}_{2}$. Mullite was still detected in some cases at temperatures of $1000^{\circ} \mathrm{C}$ or higher. The behaviors of (111) and (220) face reflection of $\mathrm{Si}$, instead of increasing, showed a gradual decline and vertually disappeared. There was a rapid decrease in the level of $Q-\mathrm{SiO}_{2}$ at $1000^{\circ} \mathrm{C}$ or higher, irrespective of the grain size of the $\alpha-\mathrm{SiC}$ and the presence or absence of $\mathrm{Si}$.

Fig. 13 shows the relationship between the grain size of the $\alpha$-SiC that was used and the peak of (220) face reflection of $\mathrm{Si}$ that developed as a result of separation. A correlation was found between the grain size of the $\alpha$-SiG and the peak of (220) face reflection of $\mathrm{Si}$ at $1300^{\circ} \mathrm{C}$. It appears that the finer $\alpha$-SiC grain sizes becomes, the more $\mathrm{Si}$ forms at high temperature. Fig. 14 shows the existence of correlation between (220) face reflection of $\mathrm{Si}$ and the $C$ $\mathrm{SiO}_{2}$ peak at $1300^{\circ} \mathrm{C}$ also seems to indicate that a part of the Si that occurs at high temperatures transforms into $C-\mathrm{SiO}_{2}$ according to the amount of $\mathrm{Si}$. Fig. 15 shows the relation between the amount of $C-\mathrm{SiO}_{2}$ that was detected at high temperatures and antioxidability. The amount of $\mathrm{C}-\mathrm{SiO}_{2}$ was determined in terms of the (220) face reflection peak of $\mathrm{Si}$

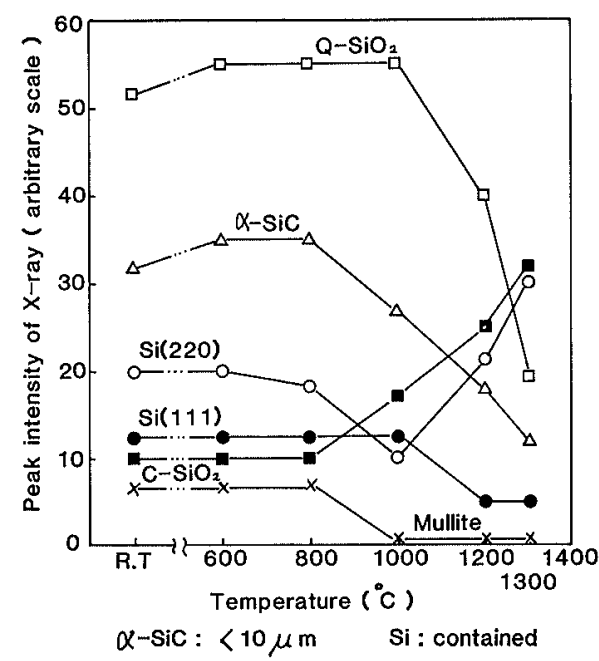

Fig. 11. Variation in composition of Si containing oxidation inhibitor with temperature.

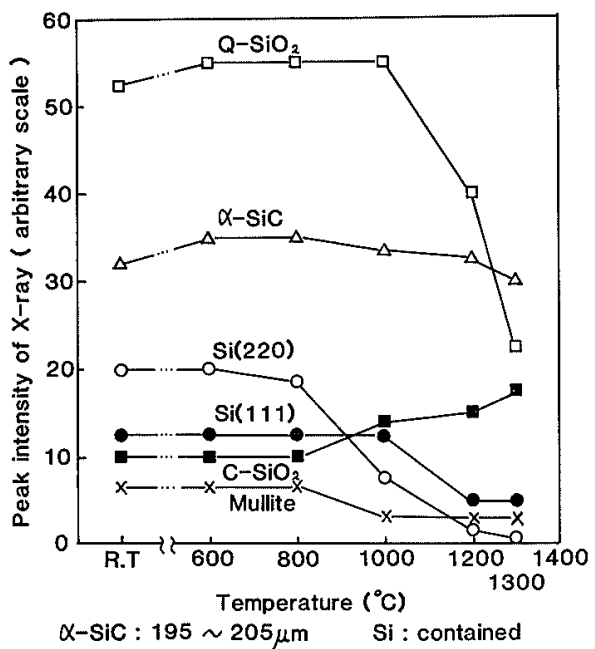

Fig. 12. Variation in composition of Si containing oxidation inhibitor with tempefature. 


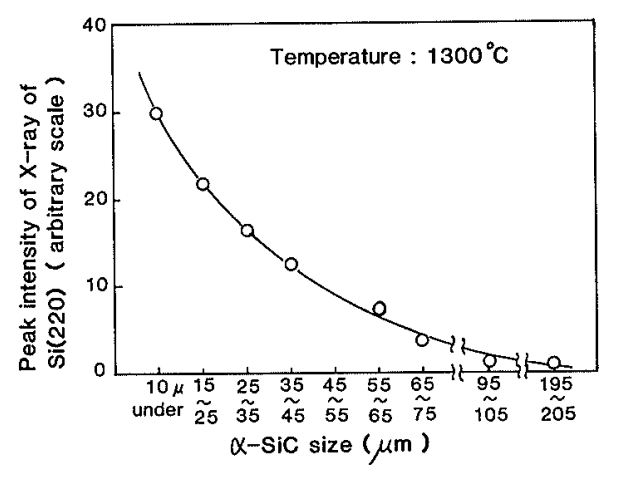

Fig. 13. Relationship between X-ray peak intensity of $\mathrm{Si}(220)$ and $\alpha$-SiC size in oxidation inhibitor at $1300^{\circ} \mathrm{C}$.

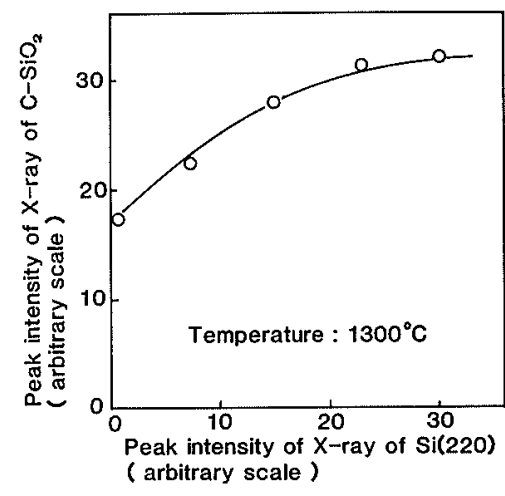

Fig. 14. Relationship between Xray peak intensity of $\mathrm{Si}$ (220) and $C-\mathrm{SiO}_{2}$ in oxidation inhibitor at $1300^{\circ} \mathrm{C}$.

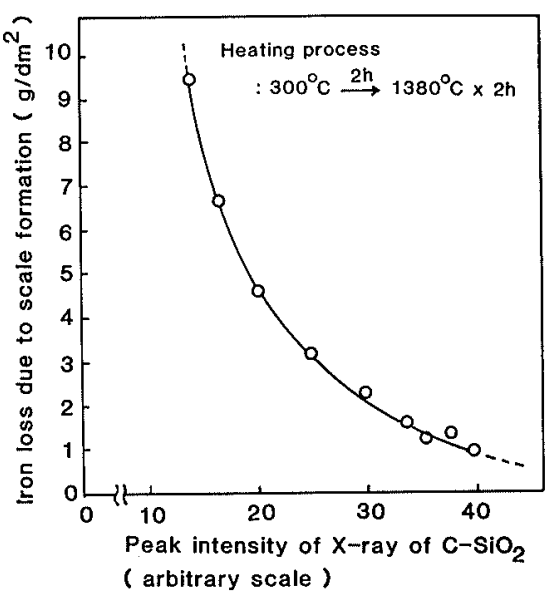

Fig. 15. Relationship between X-ray peak intensity of $\mathrm{C}-\mathrm{SiO}_{2}$ in oxidation inhibitor and iron loss due to scale formation. under conditions heated from 300 to $1380^{\circ} \mathrm{C}$ over a $2 \mathrm{~h}$ period, followed by $2 \mathrm{~h}$ soaking at $1380^{\circ} \mathrm{G}$ and antioxidability in terms of scale formation under the same heating condition. As can be seen from the diagram, antioxidability improves in proportion to the level of $C-\mathrm{SiO}_{2}$ at high temperature. The amount of $C-\mathrm{SiO}_{2}$ is formed in proportion to the amount of oxidation of $\alpha-\mathrm{SiC}$, but superior antioxidability is not possible when $\mathrm{C}-\mathrm{SiO}_{2}$ is added before hand. This suggests that a finely textured film with superior antioxidability is formed during the oxidation of $\alpha$ $\mathrm{SiC}$ to form $C-\mathrm{SiO}_{2}$. The changes that occur in the composition of $\mathrm{Si}-\mathrm{SiC}$ oxidation inhibitor films during heating are explained as following. There is a moderate decrease in $Q-\mathrm{SiO}_{2}$ during prolonged heating, but considerable amounts of $\mathrm{Si}$. $\alpha-\mathrm{SiC}$ and $C-\mathrm{SiO}_{2}$ remain, even at thigh temperatures. Mullite begins to separate at around $800^{\circ} \mathrm{C}$ and can no longer be detected at $1000^{\circ} \mathrm{C}$. The separation of the mullite is accompanied by the appearance of $\mathrm{Al}_{2} \mathrm{O}_{3}$, which was not previously detected. However, this $\mathrm{Al}_{2} \mathrm{O}_{3}$ also disappears when it is subjected to prolonged hightemperature heating. $\mathrm{Al}_{2} \mathrm{O}_{3} \cdot \mathrm{SiO}_{2}{ }^{8,9)}$ is present in all temperature zones over $800^{\circ} \mathrm{C}$ but is thought to result from the reaction of $\mathrm{Al}_{2} \mathrm{O}_{3}$ formed as a result of the separation of mullite, with either $Q-\mathrm{SiO}_{2}$ or $C-\mathrm{SiO}_{2}$. Graphite (G) is formed due to the oxidation of $\alpha-\mathrm{SiC}$ and is still present even at quite high temperatures. The presence of considerable amounts of $\mathrm{Si}$ and a little Graphite in this way indicates that a reducing atmosphere is formed within $\mathrm{Si}-\mathrm{SiC}$ oxidation inhibitor film even after prolonged high-temperature heating.

\subsubsection{Behavior of Film on Steel Surface}

A study was next carried out to determine how $\mathrm{Si}-\mathrm{SiC}$ oxidation inhibitor change on the surface of the steel.

The top of the steel (CGO steel) was coated with an $\mathrm{Si}-\mathrm{SiC}$ oxidation inhibitor and heated. The samples were recovered at each temperature level, and the condition of the film was investigated. The composition of the oxidation inhibitor used was the same as standard composition shown in Sec. 2.1.1. The condition of the film at each temperature level is shown in cross section in Fig. 16. The photograph shows a cross section of the film after application and drying in comparatively minute detail. The individual constituents are uniformly distributed. The white powder is $\mathrm{Si}$. Heating was accompanied by the evaporation of the water and the separation of the sodium polyacrylic acid, as well as the external dispersal of these substances. However, the film maintained its original condition with virtually no change. At $1200^{\circ} \mathrm{C}$, pores appeared in some areas of the film. These tended to increase somewhat at $1380^{\circ} \mathrm{C}$, but there was no significant difference from the situation at $\mathrm{I} 200^{\circ} \mathrm{C}$. It was also possible to detect large amounts of Si. After soaking for $2 \mathrm{~h}$ at $1380^{\circ} \mathrm{C}$, the number of pores inside the film increased further. Large amounts of $\mathrm{Si}$ were still present at this time.

Fig. 17 shows the results of an EPMA element analysis of the film cross section heated at various temperatures, with regard to the three elements $\mathrm{Fe}$, $\mathrm{Al}$ and $\mathrm{Si}$. The distribution of these three elements was as follows.

(i) $[\mathrm{Fe}]$

From around $800^{\circ} \mathrm{C}$, it was possible to detect signs of $\mathrm{Fe}$ dispersal to the interior of the film. As heating progressed, the dispersal layer gradually thickened. Localized peaks at the inner layer (next to the steel) all corresponded to the $\mathrm{Al}$ peak, indicating the formation of $\mathrm{Fe}-\mathrm{Al}$ compounds.

(ii) $[\mathrm{Al}]$

At low temperatures, the $\mathrm{Al}$ peaks coincided with the $\mathrm{Si}$ peak $\left(3 \mathrm{Al}_{2} \mathrm{O}_{3} \cdot 2 \mathrm{SiO}_{2}\right)$. In the medium temperature range the $\mathrm{Al}$ peaks corresponded only with the $\mathrm{O}$ peaks. This is thought to result from the formation of $\mathrm{Al}_{2} \mathrm{O}_{3}$ due to the separation of the mullite. In the high temperature range, the inner layer of the film showed the $\mathrm{Al}$ peaks corresponding to $\mathrm{Fe}$ and also to $\mathrm{Fe}$ and $\mathrm{Si}$. This points to the formation of $\mathrm{Fe}-\mathrm{Al}$ and $\mathrm{Fe}-\mathrm{Al}-\mathrm{Si}$ compounds. The $\mathrm{Al}$ and $\mathrm{Si}$ peaks again coincide in the high temperature range, 


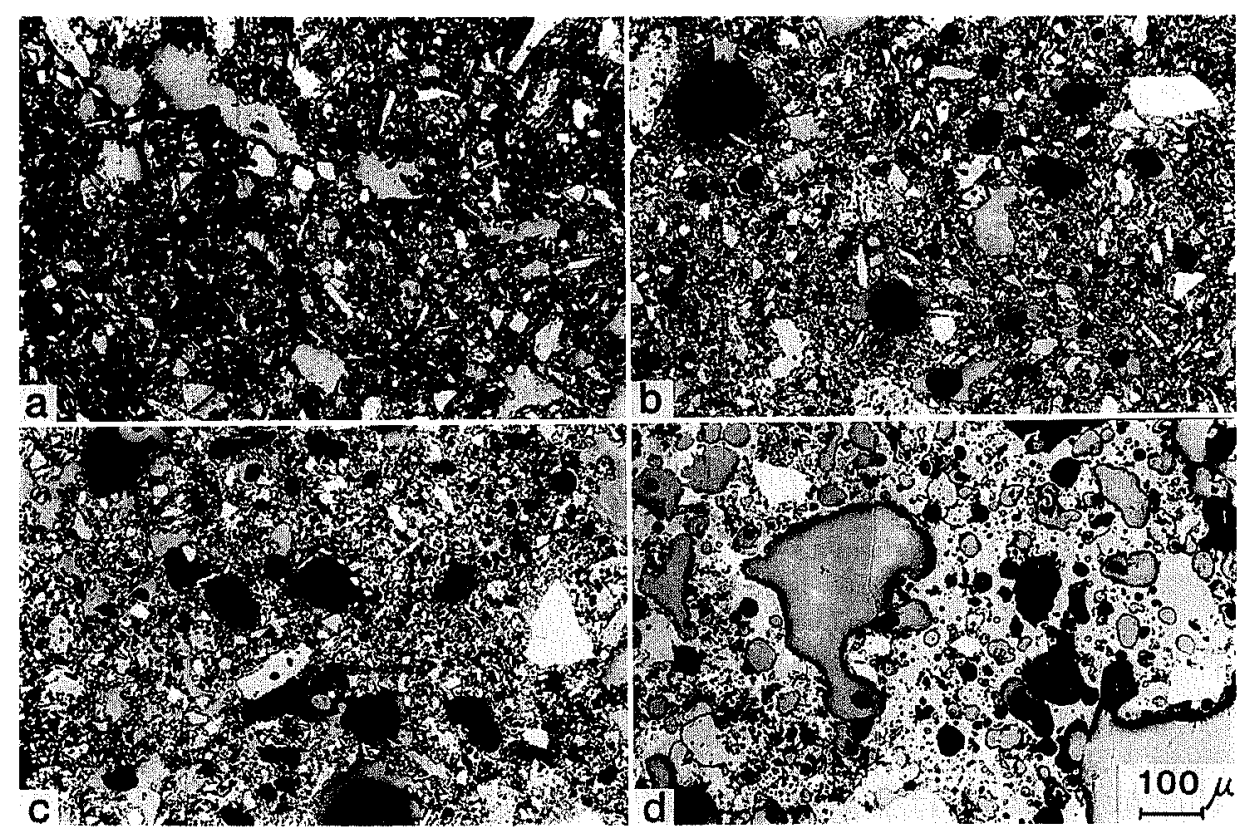
(a) $25^{\circ} \mathrm{C}$
(b) $1200^{\circ} \mathrm{C}$
(c) $1380^{\circ} \mathrm{G}$
(d) $1380^{\circ} \mathrm{C}$ for $2.0 \mathrm{~h}$

Fig. 16.

Cross section of oxidation inhibitor film at each temperature.
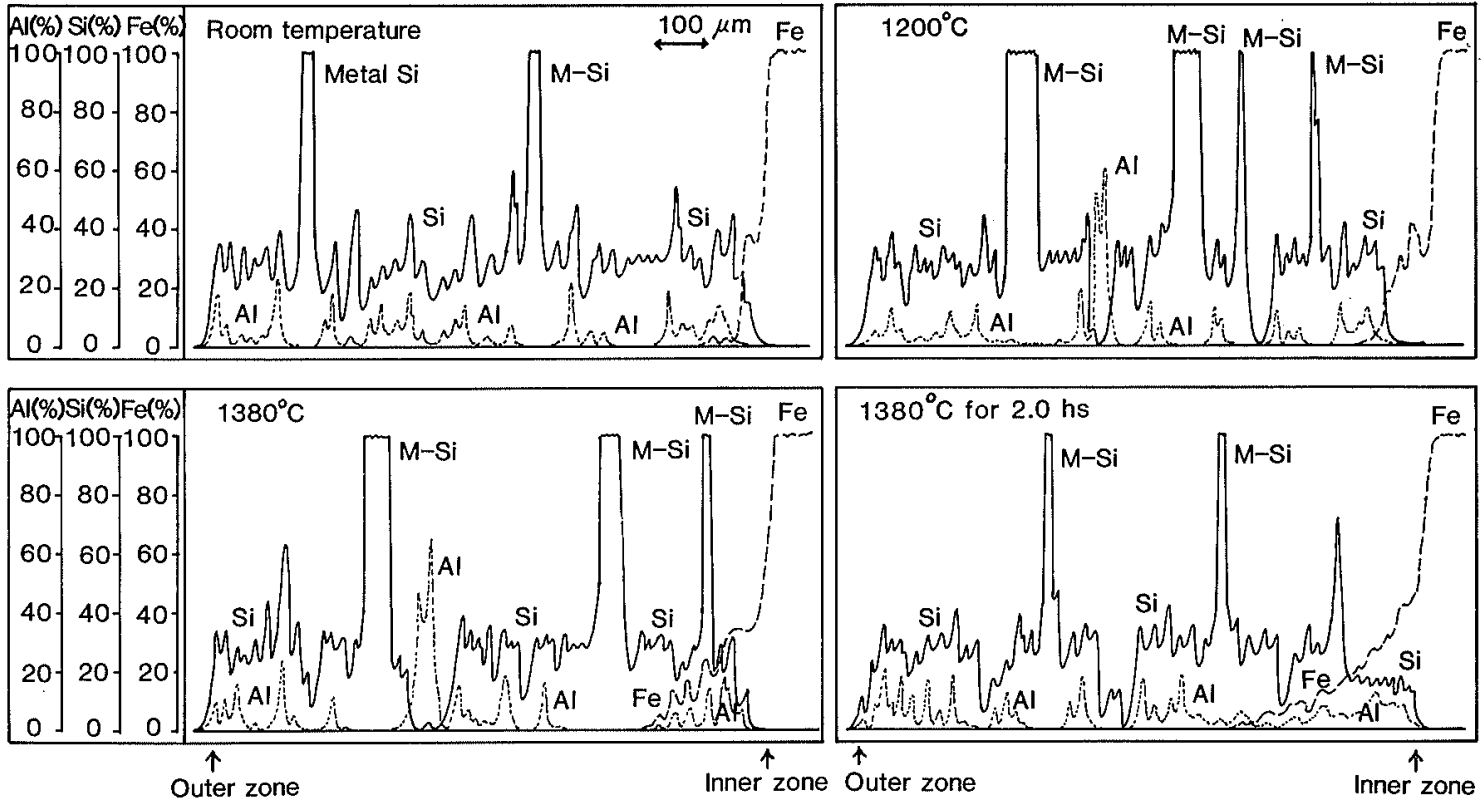

Fig. 17. Changes in the composition of an oxidation inhibitor film during heating.

but this indicates the formation of new $\mathrm{Al}-\mathrm{Si}$ composition.

\section{(iii) $[\mathrm{Si}]$}

In the low temperature range, some of the $\mathrm{Si}$ peaks do not correspond to the $\mathrm{Al}$ peaks. $3 \mathrm{Al}_{2} \mathrm{O}_{3} \cdot 2 \mathrm{SiO}_{2}$ corresponds while $\mathrm{SiO}_{2}$ does not. The number of abnormally high peaks caused by $\mathrm{Si}$ simple substance crystals increases as the temperature rises. There is absolutely no correspondence between $\mathrm{Si}$ peaks and peaks caused by the dispersal of $\mathrm{Fe}$ into the film. This means that no $\mathrm{Fe}-\mathrm{Si}$ compounds $\left(2 \mathrm{FeO} \cdot \mathrm{SiO}_{2}\right.$ etc.) were formed.

Film was next recovered at various temperature levels and powdered. It was subjected to X-ray diffraction to ascertain what changes had occurred in the composition of the film. The results are shown in Table 2. Considerable quantities of Si were detected throughout the heating period. Mullite was present in the low temperature range but could not be detected over $1000^{\circ} \mathrm{C}$. This correspond with the appearance of $\mathrm{Al}_{2} \mathrm{O}_{3}$, which also gradually disappeared in the high temperature range.

$\mathrm{Al}_{2} \mathrm{O}_{3}$ decreased, accompanied by the corresponding appearance of new compound in the form of $\mathrm{Al}_{2} \mathrm{O}_{3} \cdot \mathrm{SiO}_{2}$. This was followed by the appearance of $3 \mathrm{FeO} \cdot \mathrm{Al}_{2} \mathrm{O}_{3} \cdot 3 \mathrm{SiO}_{2}$ after $1000^{\circ} \mathrm{C}$ and $\mathrm{FeO} \cdot \mathrm{Al}_{2} \mathrm{O}_{3}$ at even higher temperatures. However, no $2 \mathrm{FeO}$. $\mathrm{SiO}_{2}$ was formed at any time during the heating period. The fact that fayalite and other substances with low melting points are not formed is a major characteristic of $\mathrm{Si}-\mathrm{SiC}$ oxidation inhibitor.

\section{Discussion}

The superior antioxidation properties of silicon steel stem from the protective effects of $\mathrm{SiO}_{2}$. However, at temperatures in exces of $1200^{\circ} \mathrm{C}$, the anti- 
Table 2. Changes in the composition of an oxidation inhibitor film on steel during heating.

\begin{tabular}{|c|c|c|c|c|c|c|c|}
\hline $\begin{array}{r}\text { Tempera } \\
\text { ture }\end{array}$ & $25^{\circ} \mathrm{C}$ & $\begin{array}{l}800 \\
{ }^{\circ} \mathrm{C}\end{array}$ & \begin{tabular}{|l|}
1000 \\
${ }^{\circ} \mathrm{C}$
\end{tabular} & \begin{tabular}{r|}
1200 \\
${ }^{\circ} \mathrm{C}$ \\
\end{tabular} & \begin{tabular}{rl|}
1380 \\
${ }^{\circ} \mathrm{C}$ \\
\end{tabular} & $\begin{array}{r}1380 \\
\mathrm{C} \\
\times \quad \\
1.0 \mathrm{~h}\end{array}$ & $\begin{array}{r}1380 \\
{ }^{\circ} \mathrm{C} \\
\times \\
2 . x^{\circ}\end{array}$ \\
\hline Si & (O) & (2) & (2) & (O) & (O) & (2) & (a) \\
\hline$\alpha-S i C$ & (2) & (a) & (2) & (2) & (2) & (2) & (a) \\
\hline$\alpha, \beta \cdot Q-\mathrm{SiO}_{2}$ & (O) & (O) & (2) & (O) & () & (2) & 0 \\
\hline$\alpha, \beta \cdot \mathrm{C}-\mathrm{SiO}_{2}$ & (2) & (2) & (2) & (O) & () & (O) & (2) \\
\hline $\mathrm{Al}_{2} \mathrm{O}_{3}$ & - & 0 & 0 & 0 & 0 & 0 & - \\
\hline $\begin{array}{l}\mathrm{Al}_{2} \mathrm{O}_{2} \mathrm{SiO}_{2} \\
\text { (Mullite) }\end{array}$ & () & 0 & 0 & - & - & - & - \\
\hline $\mathrm{Al}_{2} \mathrm{O}_{3} \mathrm{SiO}_{2}$ & - & - & 0 & 0 & 0 & 0 & 0 \\
\hline $3 \mathrm{FeO} \cdot \mathrm{Al}_{2} \mathrm{O}_{3} 3 \mathrm{SiO}_{2}$ & - & - & 0 & 0 & 0 & 0 & 0 \\
\hline $\mathrm{FeO} \cdot \mathrm{Al}_{2} \mathrm{O}_{3}$ & - & - & - & - & - & 0 & 0 \\
\hline $2 \mathrm{FeO} \cdot \mathrm{SiO}_{2}$ & - & - & - & - & - & - & - \\
\hline$\alpha-\mathrm{Fe}_{2} \mathrm{O}_{3}$ & 0 & 0 & 0 & 0 & 0 & 0 & 0 \\
\hline $\mathrm{Fe}_{3} \mathrm{O}_{4}$ & - & - & - & - & - & 0 & 0 \\
\hline$C$ & 0 & 0 & 0 & 0 & 0 & - & - \\
\hline
\end{tabular}

(a): found in abundance $\bigcirc$ : found just a little - : trace

oxidation effect actually deteriorates. ${ }^{10}$ This is due to the formation of fayalite $\left(2 \mathrm{FeO} \cdot \mathrm{SiO}_{2}\right)$, which has a low melting point. The formation of the fused phase facilitates the dispersal of ions $\left(\mathrm{Fe}^{++}, \mathrm{O}^{--}\right.$, etc. $)$, thereby accelerating the formation of scale. This means that silicon steel cannot be used at temperatures in excess of $1200^{\circ} \mathrm{C} .{ }^{1)}$ However, fayalite does not form in $\mathrm{Si}-\mathrm{SiC}$ oxidation inhibitor films. This is because the separation of the mullite produces $\mathrm{Al}_{2} \mathrm{O}_{3}$, which forms $\mathrm{FeO} \cdot \mathrm{Al}_{2} \mathrm{O}_{3}$ and $3 \mathrm{FeO} \cdot \mathrm{Al}_{2} \mathrm{O}_{3} \cdot 3 \mathrm{SiO}_{2}$ in the vicinity of the steel surface. This apparently limits the formation of $2 \mathrm{FeO} \cdot \mathrm{SiO}_{2}$.

The formation of substances with low melting points allows the film to be impossible to maintain antioxidability.

It is therefore extremely important to prevent the formation of these substances throughout the heating period.

The steel added aluminum also displays the same excellent antioxidability. However, this is believed to stem from the protective effect of $\mathrm{FeO} \cdot \mathrm{Al}_{2} \mathrm{O}_{3}$ spinel (low-aluminum steel). ${ }^{11)}$

With $\mathrm{Si}-\mathrm{SiC}$ oxidation inhibitor, $\mathrm{FeO} \cdot \mathrm{Al}_{2} \mathrm{O}_{3}$ is formed in the inner layer. This not only curbs the formation of fayalite, but also appears to possess its own powerful protective effect.

Furthermore, the fine $\mathrm{SiC}$ powder is oxidized and changes gradually to protective cristobalite- $\mathrm{SiO}_{2}(\mathrm{C}-$ $\mathrm{SiO}_{2}$ ) layer which acts as an excellent barrier to oxigen diffusion from atmosphere. The protective $C-\mathrm{SiO}_{2}$ is not formed from the $C-\mathrm{SiO}_{2}$ which is added in the oxidation inhibitor but is formed through the oxidation process of the $\mathrm{SiC}$.
The role of the synthetic mica is not clear, partly because of the low volume (approximately $1.2 \%$ ) added. It is likely that it improves the strength of the film at high temperatures, as well as helping to create a finer film. From the above discussions, the chemical reactions that take place within $\mathrm{Si}-\mathrm{SiC}$ oxidation inhibitor film can be summarized as follows.

$$
\begin{aligned}
& 3 \mathrm{Al}_{2} \mathrm{O}_{3} \cdot 2 \mathrm{SiO}_{2} \text { (Mullite) } \stackrel{\mathrm{Si}}{\longrightarrow} 3 \mathrm{Al}_{2} \mathrm{O}_{3}+2 \mathrm{SiO}_{2} \\
& \text {..................(1) } \\
& \alpha-\mathrm{SiC}+2 \mathrm{O}_{2} \rightarrow \mathrm{SiO}_{2}\left(C-\mathrm{SiO}_{2}\right)+\mathrm{CO}_{2}^{12,13)} \\
& \alpha-\mathrm{SiC}+3 / 2 \mathrm{O}_{2} \rightarrow \mathrm{SiO}_{2}\left(C-\mathrm{SiO}_{2}\right)+\mathrm{CO}^{12,13)} \\
& \alpha-\mathrm{SiC}+\mathrm{O}_{2} \rightarrow \mathrm{SiO}_{2}\left(C-\mathrm{SiO}_{2}\right)+\mathrm{C}^{(2,13)} \\
& \alpha-\mathrm{SiC}+\mathrm{O}_{2} \rightarrow \mathrm{Si}+\mathrm{CO}_{2}{ }^{12,13)} \\
& \alpha-\mathrm{SiC}+1 / 2 \mathrm{O}_{2} \rightarrow \mathrm{Si}+\mathrm{CO}^{12,13)} \\
& \mathrm{Si}+\mathrm{O}_{2} \rightarrow \mathrm{SiO}_{2}\left(C-\mathrm{SiO}_{2}\right) \\
& \mathrm{Al}_{2} \mathrm{O}_{3}+\mathrm{SiO}_{2} \rightarrow \mathrm{Al}_{2} \mathrm{O}_{3} \cdot \mathrm{SiO}_{2}^{8,9} \\
& 3 \mathrm{FeO}+\mathrm{Al}_{2} \mathrm{O}_{3}+3 \mathrm{SiO}_{2} \rightarrow 3 \mathrm{FeO} \cdot \mathrm{Al}_{2} \mathrm{O}_{3} \cdot 3 \mathrm{SiO}_{2}
\end{aligned}
$$

$$
\mathrm{FeO}+\mathrm{Al}_{2} \mathrm{O}_{3} \rightarrow \mathrm{FeO} \cdot \mathrm{Al}_{2} \mathrm{O}_{3}
$$

As the temperature rises, mullite $\left(3 \mathrm{Al}_{2} \mathrm{O}_{3} \cdot 2 \mathrm{SiO}_{2}\right)$ is first separated by the metallic $\mathrm{Si}$ that was added to
the oxidation inhibitor beforehand, forming $\mathrm{Al}_{2} \mathrm{O}_{3}$ and $\mathrm{SiO}_{2}$. At the same time, many oxidation reactions of $\alpha-\mathrm{SiC}$ are considered in heating process. ${ }^{12,13)}$ In the case of $\mathrm{Si}-\mathrm{SiC}$ oxidation inhibitor, much $\mathrm{Si}$ and $C-\mathrm{SiO}_{2}$ are formed and a little graphite is observed within the film, so it is suggested that the reactions (2) to (6) happen mainly. Oxygen dispersing into the film is captured by the formed $\mathrm{Si}$, which at the same time creates a fine and strongly protective film of $C-\mathrm{SiO}_{2}$. The film prevents any further dispersal of oxygen and improves antioxidability. These reactions are accelerated due to the application of the fine-SiC and the metallic Si added beforehand in the oxidation inhibitor.

Meanwhile, part of the $\mathrm{Al}_{2} \mathrm{O}_{3}$ that was produced by the separation of the mullite combines with $\mathrm{SiO}_{2}$ to form $\mathrm{Al}_{2} \mathrm{O}_{3} \cdot \mathrm{SiO}_{2}$. Near the surface of the steel, however, it forms $\mathrm{FeO} \cdot \mathrm{Al}_{2} \mathrm{O}_{3}$ or $3 \mathrm{FeO} \cdot \mathrm{Al}_{2} \mathrm{O}_{3} \cdot 3 \mathrm{SiO}_{2}$. Fig. 18 is a diagrammatic representation of these various reaction mechanisms.

Finally let us consider the flaking characteristics of Si-SiC oxidation inhibitor films during hot rolling. The superior flakability of $\mathrm{Si}-\mathrm{SiC}$ oxidation inhibitor films can probably be explained in the following terms. The adhesive nature of viscous substances generally makes it extremely difficult to remove them in a short period of time through spraying with highpressure water and so on. The combination of the antioxidant film with steel or scale to form substances with low melting points will therefore seriously obstruct flaking characteristics of film. The fact that absolutely no substances with low melting points $\left(2 \mathrm{FeO} \cdot \mathrm{SiO}_{2}\right.$ etc.) are formed in $\mathrm{Si}-\mathrm{SiC}$ oxidation inhibitor represents a considerable advantage in terms of flakability. The superior flakability of Si-SiC oxidation inhibitor during hot rolling is primarily due to this factor. 


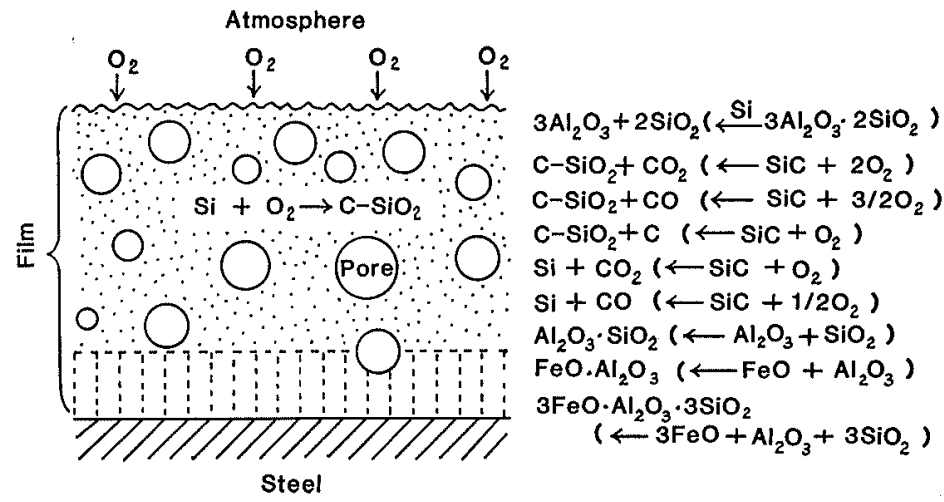

Fig. 18.

Schematic representation of antioxidation mechanism of oxidation inhibitor film.

\section{Conclusion}

The following conclusions are based on the results of an investigation of the newly developed $\mathrm{Si}-\mathrm{SiC}$ oxidation inhibitor (refractory powder- $\mathrm{SiO}_{2}-\mathrm{Si}-\mathrm{SiC}-$ synthetic mica-colloidal silica-surface active agentcaking bond oxidation inhibitor) and studies regarding the oxidation inhibitor mechanism of these substances.

\subsection{Oxidation-preventive Capacity}

Si-SiC oxidation inhibitor displayed excellent antioxidability with $3 \% \mathrm{Si}$ steels. It was possible to reduce scaling and the formation of fayalite $(2 \mathrm{FeO}$. $\mathrm{SiO}_{2}$ ) slag to $1 / 20-1 / 30$ compared with uncoated samples with applications at the rate of $1.0 \mathrm{~kg} / \mathrm{m}^{2}$, and to $1 / 80-1 / 100$ with application at $1.5 \mathrm{~kg} / \mathrm{m}^{2}$. Confirmation of these characteristics on the production line revealed that scaling and slag formation was eliminated, leading to substantial improvements in yield. Also, the film showed excellent flakability during hot rolling and had separated completely by the time the samples passed through the RSB, leaving absolutely no traces of residual film at the finished product stage. $\mathrm{Si}-\mathrm{SiC}$ oxidation inhibitor also showed superior heat conductivity and heat absorption, and there was virtually no difference between the coated and uncoated samples in terms of the post-heating condition of the steel. This means that there is no difference between the coated and uncoated samples in terms of magnetism, and the same level of magnetism is recoaded with steel that has been coated with $\mathrm{Si}-\mathrm{SiC}$ oxidation inhibitor as compared with uncoated steel.

\subsection{Mechanism of Oxidation Inhibition}

The oxidation inhibition mechanisms of $\mathrm{Si}-\mathrm{SiC}$ oxidation inhibitor are as follows.

During heating, the metallic Si that is added to the $\mathrm{Si}-\mathrm{SiC}$ oxidation inhibitor beforehand breaks down the mullite $\left(3 \mathrm{Al}_{2} \mathrm{O}_{3} \cdot 2 \mathrm{SiO}_{2}\right)$ that is contained in the refractory powder to produce $\mathrm{Al}_{2} \mathrm{O}_{3}$. Furtheremore, the fine $\mathrm{SiC}$ powder is oxidized and changes gradually to protective cristobalite- $\mathrm{SiO}_{2}\left(C-\mathrm{SiO}_{2}\right)$ layer which acts as an excellent barrier to oxigen diffusion from atmosphere. The protective $C-\mathrm{SiO}_{2}$ is not formed from the $C-\mathrm{SiO}_{2}$ which is added initially but is newly formed through the oxidation process of the $\mathrm{SiC}$.

Meanwhile, the $\mathrm{Al}_{2} \mathrm{O}_{3}$ formed by the separation of the mullite combines with $\mathrm{SiO}_{2}$ to form $\mathrm{Al}_{2} \mathrm{O}_{3} \cdot \mathrm{SiO}_{2}$. However, at the steel surface, $\mathrm{FeO} \cdot \mathrm{Al}_{2} \mathrm{O}_{3}$ or $3 \mathrm{FeO}$. $\mathrm{Al}_{2} \mathrm{O}_{3} \cdot 3 \mathrm{SiO}_{2}$ were formed, creating a highly protective film and curbing the formation of substances with low melting points, such as fayalite $\left(2 \mathrm{FeO} \cdot \mathrm{SiO}_{2}\right)$. It was found that these complex effects were responsible for the extremely good antioxidability of $\mathrm{Si}-\mathrm{SiC}$ oxidation inhibitor.

\subsection{Strippability of Film}

It was found that the excellent flakability of $\mathrm{Si}$ $\mathrm{SiC}$ oxidation inhibitor during hot rolling stemmed from the fact that $2 \mathrm{FeO} \cdot \mathrm{SiO}_{2}$ and other substances with low melting points were not formed during heating.

\section{REFERENCES}

1) T. Araki, S. Morioka, K. Hisamatsu, K. Fueki, S. Shimodaira and N. Otani: The Science of Iron and Steel Corrosion, Iron and Steel Lecture No. 11, Asakura Shoten, Tokyo, (1972), 56.

2) H. Odashima, M. Kitayama and S. Maeda: Trans. Iron Steel Inst. Jpn., 27 (1987), 110.

3) Japanese Patent Publication 55-038408, (1980).

4) Japanese Patent Publication 56-026693, (1981).

5) Japanese Patent Publication 58-48008, (1983).

6) Japanese Patent Publication 59-21925, (1984).

7) Japanese Patent No. 57-39122, (1982).

8) A. Muan: J. Am. Ceram. Soc., 40 (1957), 127.

9) J. W. Welch: Nature, 186 (1960), 546.

10) M. Sugiyama: The Heating and Oxidation of Metal Materials, Seibundo-Shinkosha, Tokyo, (1964), 113.

11) M. Sugiyama: The Heating and Oxidation of Metal Materials, Seibundo-Shinkosha, Tokyo, (1964), 109.

12) G. Ervin: J. Am. Ceram. Soc., 41 (1958), 347.

13) B. Yoshiki: Fire-Resistant Material Engineering, Jihodo, Tokyo, (1963), 525. 